\title{
The silent spring of Sargassum
}

\section{Damien A. Devault ${ }^{1} \cdot$ Emma Modestin $^{2} \cdot$ Victoire Cottereau $^{3} \cdot$ Fabien Vedie $^{4} \cdot$ Valérie Stiger-Pouvreau $^{5}$.

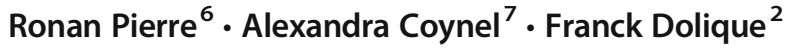

Received: 18 April 2020 / Accepted: 22 December 2020 / Published online: 12 January 2021

(C) The Author(s), under exclusive licence to Springer-Verlag GmbH, DE part of Springer Nature 2021

Sargassum is a genus of brown macroalgae (Phaeophyceae, Fucales) spread worldwide in tropical, subtropical, and temperate environments. All Sargassum species are benthic except for two pelagic ones: Sargassum natans and S. fluitans, previously confined to the Gulf of Mexico and Sargasso Sea and now drifting on the surface of the tropical Atlantic Ocean where they accrete together into windrows of floating thalli, ranging in size from large patches to rafts of several hundred metres in length (Ody et al. 2019). Climate events (hurricanes, rises in seawater temperature) and sea current events (anomalies in surface currents) could spread them onshore, but those algae have never been reported significantly elsewhere. However, since 2011, large beaching events have been occurring on the shores of West Africa (Sankare et al. 2016) and the Greater Caribbean (Langin 2018). Initially episodic, such beachings are tending to become increasingly frequent and massive, due to an unexpected location of growth in front of the Amazonian Mouth (Johns et al. 2020). The hypotheses proposed to explain this are a link with some cause within

Responsible Editor: Philippe Garrigues

Damien A. Devault

damien.devault@univ-mayotte.fr

1 Département des Sciences et Technologies, Centre Universitaire de Formation et de Recherche de Mayotte, RN3, BP53, 97660 Dembeni, Mayotte, France

2 UMR BOREA, BP 7209, 97275 Schœlcher, Martinique, France

3 UMR 7301 MIGRINTER, Université de Poitiers, Bat. A5 - TSA 21103, 5 Rue Théodore Lefebvre, 86073 Poitiers Cedex 9, France

4 DEAL Martinique, Route de la Pointe de Jaham, BP7212, 97274 Schœlcher, Martinique, France

5 UMR 6539 LEMAR, Institut Universitaire Européen de la Mer, Université de Bretagne Occidentale Technopôle Brest-Iroise, rue Dumont d'Urville, 29280 Plouzané, France

6 CEVA, Presqu'île de Pen Lan, 22610 Pleubian, France

7 UMR 5805 EPOC, Université de Bordeaux, Allée Geoffroy Saint-Hilaire, CS 50023, 33615 Pessac Cedex, France the raft (Lapointe et al. 2014), the deforestation of inner Amazonia, and/or African coastal mangroves or the expansion of the Sahara (Sissini et al. 2017; Oviatt et al. 2019; Wang et al. 2019). The large volumes involved show a trend of yearly increase and can be expressed in millions of tons of algae that have drifted to shores, leading to severe impacts on the environment and human health: Sargassum pile up on the shore, then decay, producing foul and corrosive hydrogen sulphide, and depleting oxygen in water; colloidal bleed is also observed (Perry et al. 2018). Such events have overwhelmed public authorities and endangered economic activities, mainly in the tourism sector and port industries and infrastructures. Sargassum is also described as a "health issue" by France's regional health agencies, because it now represents a real threat to human health. Several French doctors have already sent out alerts on this problem through a publication (Resiere et al. 2018). They confirm that there is a pressing need to discuss this matter at an international level with a view to boosting marine research, pooling resources, and consolidating local political priorities. Between January and August 2018, health professionals reported 3341 cases in Guadeloupe (West Indies) and 8061 cases in Martinique (West Indies), of which three patients were admitted to intensive care. Otherwise, beaching consequences are currently under intensive study as macroscopic pollution. However, Sargassum beachings pose another more insidious threat. Until now, arsenic concentration in geochemical backgrounds of the Caribbean islands has generally been low, but Michel (1985), Muse et al. (1989), Neff (2002), Pell et al. (2013), and Devault et al. (2019) have highlighted that the Sargassum content of arsenic gives cause for concern: arsenic (As) is a notorious toxic metalloid. Naturally present in soils and water, arsenic is commonly found in sulphide-bearing mineral deposits mainly associated with gold, antimony, silver, lead, copper, tin, zinc, and iron minerals. Amongst the three other valency states of As (As-3, As-III, and As-V), As-3 is found only at extremely low redox values, i.e. in highly-reducing environments (Moore and Ramamoorthy 1984). Arsenite 
As-III is dominant in reducing environments, and arsenate As$\mathrm{V}$ prevails in oxidising conditions: As-III and $\mathrm{As}-\mathrm{V}$ are observed in marine conditions, with As-V being more commonly reported because the oxidising environment is more common than the reducing one (Sadiq 1990; Anderson and Bruland 1991a, b; Francesconi and Edmonds 1998; etc.). Above all, arsenic is a Va group element and is related to other Va group elements (e.g. antimony and phosphorus): its behaviour in the environment is close to that of phosphorus (Neff 2002), leading As to compete with phosphorus for adsorption sites (Neff 1997). Arsenate can be assimilated by algae in the As-V oxidation state through phosphate transporters, as described by Bouain et al. (2014), owing to its physicochemical similarities with $\mathrm{P}\left(\mathrm{H}_{2} \mathrm{PO}_{4}^{-}\right.$versus $\left.\mathrm{H}_{2} \mathrm{AsO}^{-}\right)$(Taylor and Jackson 2016), leading to a subsequent decrease of phosphorus in the tissues of algae receiving rising concentrations of $\mathrm{As}(\mathrm{V})$. Arsenate is predominant in organic aqueous and aerobic environments and is strongly adsorbed on to the surface of several aquatic organisms and oxidised minerals of $\mathrm{Fe}, \mathrm{Mn}$, and $\mathrm{Al}$ (Al Mamun et al. 2018 and 2019), including inner iron plaques in Sargassum. But mobilisation via reduction processes can occur in the water column or sediments. Previous studies have highlighted that the average concentrations recorded for floating Sargassum thalli range from 80 to $140 \mathrm{mg} / \mathrm{kg}$ of the dry weight (dw) of the alga (Michel 1985; Devault et al. 2019): no explanation has yet been found for such variations. Given the mean concentration in arsenic, assessing the total amount of stranded Sargassum on a given territory requires considerable resources that have not yet been utilised for a whole episode. However, a one-shot complete assessment performed on September 27, 2014, in Martinique (West Indies) during an airborne survey concluded that there was a total amount of $34,000 \mathrm{~m}^{3}$ of fresh floating Sargassum contiguous to the shoreline. Considering an average of $250 \mathrm{~kg} / \mathrm{m}^{3}$, $31 \%$ dry weight rate, and an arsenic concentration of $80 \mathrm{mg} / \mathrm{kg}(\mathrm{dw})$, the total influx of arsenic was about $210 \mathrm{~kg}$ in only a few days. Despite variations in time and intensity, the Martinique shoreline has experienced a total of 37 months of heavy stranding episodes since 2011. In theory, this has led to several tons of arsenic spread along the exposed coastline of the island due to Sargassum beaching. Occurring year after year, is it possible for this influx to contaminate biota? In other words, is this arsenic bioavailable?

When Sargassum thalli are massively accreted in shallows or on floating dams in stress conditions (which have to be defined more precisely), they transudate - a phenomenon that is visible to the naked eye. Such transudation has scarcely been studied (de Carvalho et al. 1994; Figuiera et al. 2000; Davis et al. 2004; Veit et al. 2014; and more recently, Perry et al. 2018), but has been identified as colloidal leaks. The phenomenon has never been evaluated quantitatively, and indirect data show a range from 1.6 to $49 \%$ of dried biomass (Veit et al. 2014 and Figuiera et al. 2000, respectively) depending on the species studied and how the biomass is handled. Ender et al. (2019) propose that the bulk of the arsenic is adsorbed on the cell walls due to the polysaccharides that structure the cell wall of brown algae, therefore due to the alginate content. If oceanic streams do not drift the raft westward into the Caribbean Sea, stressed Sargassum sink and their decaying close to the sediment produces a mud close in density to fluid mud (as defined by Thouvenin et al. 1994; Abril et al. 2003, 2004); the fate of arsenic content in fluid mud is unknown, including its speciation in the more toxic As-III, but arsenic input may be expected to be mostly bioavailable.

Moreover, the Caribbean population traditionally eats bivalves, which are known for filtering high volumes of seawater and for bioaccumulating micropollutants. The average fish and other seafood consumption is apparently well below the world average (8.96 versus $18.98 \mathrm{~kg} /$ capita/year) (Faostat 2013), probably also because shellfish and especially bivalves are not a traditional element in the diet of Caribbean peoples (Josupeit 2011). However, bivalves are widely targeted by the subsistence coastal fisheries in the Caribbean. Local artisanal fisheries play a significant role in the livelihoods and food security of more than two million people (de Oliveira Leis et al. 2019). Many healthcare professionals are seeing an increase in consultations with local populations due to the effects of chronic exposure to hydrogen sulphide (Resiere et al. 2018). However, the health consequences of long-term exposure to arsenic from bivalves remain poorly documented and impede hospitals from understanding this reality. This value can reach more than $5 \mathrm{mg} / \mathrm{kg}$ (dw) (Sloth et al. 2005), but as Francesconi (2010) and Zmozinski et al. (2015) have demonstrated, trimethylated arsenobetaine dominates quantitatively in the multiple arsenic species in seafood due to arsenic speciation. Amongst the tri- and tetramethyl As forms, including arsenobetaine, arsenic toxicity varies according to the degree of methylation: in decreasing order, MMA(III) and DMA(III) $>$ arsenous acid $(\mathrm{As}(\mathrm{III}))>$ As acid or arsenate $(\mathrm{As}(\mathrm{V}))>>$ monomethylarsonic acid $(\mathrm{MMA}(\mathrm{V})) \approx$ dimethylarsinic acid $(\mathrm{DMA}(\mathrm{V}))>$ trimethylated species (arsenobetaine (AsB), etc.) (Geng et al. 2009).

Arsenobetaine is known to be slightly toxic $\left(\mathrm{LD}_{50} \approx\right.$ $10 \mathrm{~g} / \mathrm{kg}$ ), but the other forms have acute $\mathrm{LD}_{50}$ of $5-100 \mathrm{mg} / \mathrm{kg}$ body: with chronic tolerance daily intake (TDI) for inorganic

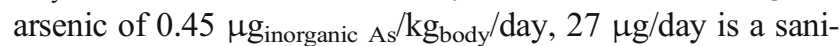
tary threshold following the international standard for an adult $(60 \mathrm{~kg})$. TDI for organic species is not known, partly because data for MMA(III) and DMA(III) are scarce, and partly because the other organic species of As- $\mathrm{V}$ are slightly toxic. During beaching events, bioavailable arsenic accumulation is not studied, nor the conversion of the seaweed arsenosugars, and the time needed to turn input of inorganic arsenic into 
arsenobetaine needs to be determined, at least to estimate the duration between the Sargassum beaching and re-entry to the harvesting site.

The challenge is compounded by the lack of knowledge about arsenic speciation and bioavailability and about coastal streams inducing dilution and drift. However, year after year, arsenic contamination will be maintained by the increasing beached volumes. Such a concern has to be solved at an international scale due to the extent of the problem, but collaboration at the scale of beaching events, i.e. along West Africa, the USA, and the Caribbean basin, is in its infancy. At the local scale, arsenic concern is ignored by most stakeholders and the governance is not aware of it, except for the French West Indies; yet even for the FWI, there is room for improvement and scientific means must be mobilised. In particular, caution must be exercised with regard to the use of stranded Sargassum biomass by local populations.

\section{References}

Abril G, Etcheber H, Delille B, Frankignoulle M, Borges AV (2003) Carbonate dissolution in the turbid and eutrophic Loire estuary. Mar Ecol Prog Ser 259:129-138

Abril G, Commarieu M-V, Maro D, Fontugne M, Guérin F, Etcheber H (2004) A massive dissolved inorganic carbon release at spring tide in a highly turbid estuary. Geophys Res Let 31(9):1-4

Al Mamun MA, Omori Y, Papry RI, Kosugi C, Miki O, Rahman IMM, Mashio AS, Maki T, Hasegawa H (2018) Bioaccumulation and biotransformation of arsenic by the brown macroalga Sargassum patens C. Agardh in seawater: effects of phosphate and iron ions. J Appl Phycol 31(4):2669-2626

Anderson LCD, Bruland KW (1991a) Biogeochemistry of arsenic in natural waters: the importance of methylated species. Environ Sci Technol 25(3): 420-427. 85

Anderson LCD, Bruland KW (1991b) Biogeochemistry of arsenic in natural waters: the importance of methylated species. Environ Sci Technol 25(3):420-427

Bouain N., Shahzad,Z. Rouached,A. Abbas Khan G., Berthomieu P., Abdelly C., Poirier Y., Rouached Y. (2014) Phosphate and zinc transport and signalling in plants: toward a better understanding of their homeostasis interaction. Journal of Experimental Botany, 65(20):5725-5741. https://doi.org/10.1093/jxb/eru314

Davis TA, Ramirez M, Mucci A, Larsen B (2004) Extraction, isolation and cadmium binding of alginate from Sargassum spp. J Appl Phycol 16:275-284

de Carvalho RP, Chong K-H, Volesky B (1994) Effects of leached alginate on metal biosorption. Biotechnol Lett 16(8):875-880

de Oliveira Leis M, Barragán-Paladines MJ, Saldaña A, Bishop D, Hong J, Kereži J, Agapito M, Chuenpagdee R (eds) (2019) Overview of small-scale fisheries in Latin America and the Caribbean: challenges and prospects. In: Viability and Sustainability of Small-Scale Fisheries in Latin America and the Caribbean. MARE Publication Series, vol 19. Springer, Cham

Devault DA, Massat F, Dupuy L, Lambourdière J, Ménez F, Maridakis C, Hervé V, Péné-Annette A, Trouillefou M, Dolique F, Lopez P-J (2019. Sargassum contamination by chlordecone: the other challenge of Sargassum beachings in the West Indies. $39^{\text {th }}$ colloquium of French research Group about Pesticides, Montpellier, 21 to 24 May 2019
Ender E, Subirana MA, Raab A, Krupp EM, Schaumlöffel D, J Feldmann (2019) Why is NanoSIMS elemental imaging of arsenic in seaweed (Laminaria digitata) important for understanding of arsenic biochemistry in addition to speciation information? J. Anal. At. Spectrom. 1-8 In press

FAOSTAT (2013) Fishery statistical collections: consumption of fish and fishery products database accessed on $26 / 03 / 2020$

Figuiera MM, Volesky B, Ciminelli VST, Roddick FA (2000) Biosorption of metals in brown seaweed biomass. Wat Res 34(1): 196-204

Francesconi KA (2010) Arsenic species in seafood: origin and human health implications. Pure Appl Chem 82(2):373-381

Francesconi KA, Edmonds JS (1998) Arsenic species in marine samples. Croat Chem Acta 71(2):343-359

Geng W, Komine R, Ohta T, Nakajima T, Takanashi H, Ohki A (2009) Arsenic speciation in marine product samples: comparison of extraction-HPLC method and digestion-cryogenic trap method. Talanta 79:369-375

Johns EM, Lumpkin R, Putman NF, Smith RH, Muller-Karger FE, Rueda-Roa DT, Hu C, Wang M, Brooks MT, Gramer LJ, Werner FE (2020) The establishment of a pelagic Sargassum population in the tropical Atlantic: biological consequences of a basin-scale long distance dispersal event. Prog Oceanog 182:102269

Josupeit, H. 2011. Consumption patterns for fish and seafood in the Caribbean with special emphasis on bivalves and univalves. In A. Lovatelli and S. Sarkis (eds). A regional shellfish hatchery for the Wider Caribbean: assessing its feasibility and sustainability. FAO Regional Technical Workshop. 18-21 October 2010, Kingston, Jamaica. FAO Fisheries and Aquaculture Proceedings. No. 19. Rome, FAO. 2011. pp. 199-246

Langin K (2018) Seaweed masses assault Caribbean islands. Science 360(6394):1157-1158

Lapointe BE, West LE, Sutton TT, Hu C (2014) Ryther revisited: nutrient excretions by fishes enhance productivity of pelagic Sargassum in the western North Atlantic Ocean. J Exper Mar Biol Ecol 458:46-56

Michel P (1985) Arsenic in marine environment: bibliographic summary. Reu. Trau. Inst. Pèches Marit. 49 (3 and 4): 175-185. In French

Moore JW, Ramamoorthy S (1984) Heavy metals in natural waters: applied monitoring and impact assessment. Applied Monitoring and Impact Assessment, Spinger-Verlag, New York Inc. 1-247pp. ISBN 978-1-4612-5210-8

Muse JO, Tudino MB, d'Huicque L, Troccoli OE, Carducci CN (1989) Atomic absorption spectrometric determination of inorganic and organic arsenic in some marine benthic algae of the southern Atlantic coasts. Environ Poll 58:303-312

Neff JM (1997) Ecotoxicology of arsenic in the marine environment. Environ Toxicol Chem 16(5):917-927

Neff JM (2002) Arsenic in the ocean. In: Bioaccumulation in Marine Organisms. 468pp. 57-78 Elsevier Ltd ISBN 978-0-08-043716-3

Ody A, Thibaut T, Berline L, Changeux T, Andre' J-M, Chevalier C et al (2019) From in situ to satellite observations of pelagic Sargassum distribution and aggregation in the Tropical North Atlantic Ocean. PLoS One 14(9):e0222584

Oviatt CA, Huizenga K, Rogers CS, Miller WJ (2019) What nutrient sources support anomalous growth and the recent Sargassum mass stranding on Caribbean beaches? A review. Mar Pollut Bull 145: $517-525$

Pell A, Kokkinis G, Malea P, Pergantis SA, Rubio R, López-Sánchez JF (2013) LC-ICP-MS analysis of arsenic compounds in dominant seaweeds from the Thermaikos Gulf (Northern Aegean Sea, Greece). Chemosphere 93:2187-2194

Perry RA, Vaudrey JMP, Dierssen HM (2018) Long range transport and carbon and nitrogen dynamics of floating seagrass wracks in Greater Florida Bay. Est CoastShelf Sci 209:7-17

Resiere D, Valentino R, Nevière R, Banydeen R, Gueye P, Florentin J, Cabié A, Lebrun T, Mégarbane B, Guerrier G, Mehdaoui H (2018) 
Sargassum seaweed on Caribbean islands: an international public health concern. Lancet 392:2691

Sadiq M (1990) Arsenic chemistry in marine environments: a comparison between theoretical and field observations. Mar Chem 31(1-3):285297

Sankare Y, Komoe K, Aka K-S, Fofie N'B-Y, Bamba A (2016) Répartition et abondance des sargasses Sargassum natans et Sargassum fluitans (Sargassaceae, Fucales) dans les eaux marines ivoiriennes (Afrique de l'Ouest). Intern J Biolog Chem Sci 10(4): 1853-1864 In French

Sissini MN, de Barros Barreto MBB, Szechy MTM, de Lucena MB, Oliveira MC, Gower J, Liu G, de Oliveira BE, Milstein D, Gusmao F, Martinelli-Filho JE, Alves-Lima C, Colepicolo P, Ameka G, de Graft-Johnson K, Gouvea L, Torrano-Silva B, Nauer F, Marcos de Castro Nunes J, Barufi JB (2017) The floating Sargassum (Phaeophyceae) of the South Atlantic Ocean-likely scenarios. Phycologia 56(3):321-328

Sloth JJ, Larsen EH, Julshamn K (2005) Survey of inorganic arsenic in marine animals and marine certified reference materials by anion exchange high-performance liquid chromatography-inductively coupled plasma mass spectrometry. J Agric Food Chem 53(15): $6011-6018$
Taylor VF, Jackson BP (2016) Concentrations and speciation of arsenic in New England seaweed species harvested for food and agriculture. Chemosphere 163:6-13

Thouvenin B, Le Hir P, Roman LA (1994) Dissolved oxygen model in the Loire estuary, in Changes in fluxes in estuaries: implications from science to management, edited by KR Dyer and RJ Orth, pp. 169-178, Olsen and Olsen, Fredensborg, Denmark

Veit MT, da Cunha GG, Fagundes-Klen MR, da Silva EA, Granhen Tavares CR, Ferandin Honorio J (2014) Organic leaching and metal removal with Sargassum filipendula. Acta Scientiarum Technol 36(3):429-435

Wang M, Hu C, Barnes BB, Mitchum G, Lapointe B, Montoya JP (2019) The great Atlantic Sargassum belt. Sci 365(6448):83-87

Zmozinski AV, Llorente-Mirandes T, López-Sánchez JF, da Silva MM (2015) Establishment of a method for determination of arsenic species in seafood by LC-ICP-MS. Food Chem 173:1073-1082

Publisher's note Springer Nature remains neutral with regard to jurisdictional claims in published maps and institutional affiliations. 